\title{
Evaluation Of Soja Productivity (Imperial Variete And Canada) In Association With Maize (Bamboo Variete) In The Ecological Conditions Of Sustainable Use Of Sake / Nord Kivu
}

\author{
Marcel Bwama Meyi ${ }^{1}$, Musungay Viviane ${ }^{2}$, Grégoire Mashala Bitwakamba ${ }^{3}$ and \\ Romeo Ciminello ${ }^{4}$
}

\begin{abstract}
With a view to using land capital in an efficient and effective manner with a view to encouraging sustainable development in this ecological area of North Kivu; and to help minimize land-use conflicts, we have thought of establishing a combination of crops (soybean and maize) as a technique that can help maximize yields / ha and household income, while maintaining the fertility gradient of the soil. The effectiveness of Soybean-maize associations offers interesting prospects for improving the sustainability of production systems.

The trial was arranged in randomized randomized blocks with 5 treatments and 3 replicates. For this study we used 2 soybean varieties that are: imperial and canada, with a variety of corn (bamboo).

The arrangement of the association was of the type MBILI-MOJA which means two Soya lines intercepted by a corn line. The parameters studied were the phenological and productive parameters which are: survey rate, neck diameter, height at flowering, number of leaves per foot, average number of pods per plant for soybean, average number of seeds of soybean pod, percentage of pod burst, soybean biomass removal, number of ears per plant, weight of 100 soybean and corn seeds, plot production (in $\mathrm{kg}$ ), yield per tonne per hectare and the LER.

The GENSTAT descovery software allowed us to analyze the variance of our data and the averages were separated using the PPDS at the 5\% threshold. The performance of the associations was as follows:

Imperial: 1,6 L.E.R =, L.E.R $>1$ (there is a productive advantage in this association with corn bamboo); Canada: 2,33 LER $=$, LER $>1$ (there is a productive advantage in this association with bamboo maize.) In both cases, there is maintenance of biodiversity and soil fertility.

with maize as the imperial variety, that of 2.33 by the performance of LER. Fertility of the soil has been maintained from this technique which promotes soil and atmospheric nitrogen which crops need for their growth and productivity.
\end{abstract}

Keywords: Soybean, maize, Association, Development sustainability, LER, SAKE / North Kivn

\section{Introduction}

To alleviate food insecurity and effectively combat poverty in the Democratic Republic of Congo, combining mixed crops or crops with limited land expanses contributes to soil fertility and sustainable development.

Since the 1980s, agriculture has emerged as the largest economic sector in the country in terms of GDP and employment with growing importance (FAO, 2009).

\footnotetext{
1'University of Kisangani (UNIKIS) and National Pedagogical University (UPN / KIN);

2 Goma University/RDC Phd Student

${ }^{3}$ University Notre-Dame of Kasayi (U.KA.) and Catholic University of Congo (UCC / KIN);

${ }^{4}$ Rector of Hermes Popular Private University ets in Rome, Italy.
} 
Agriculture in Africa is of vital importance, but many farmers need support to meet some

of the

challenges.

Despite many advances, there is precariousness and severe food insecurity caused by the succession of war, looting, theft, insecurity and the displacement of the population. The food problem is particularly acute in the African continent due to population growth, insufficient plowed area and the practice of rudimentary techniques (Kroll, 1994).

Due to the city's rate of population growth and urbanization, declining soil fertility and erosion mean that harvests become low to meet the needs of the population whose demand remains rigid. The problem of land and agricultural capital arises with acquittal and becomes a source of conflict permanently in this part of the country (Ruremesha, K 2019).

The population of North Kivu has staple foods such as beans, maize, rice, potatoes, sweet potatoes, cassava, etc. Apart from its local production, it is supplied by the neighboring countries (Rwanda and Uganda).

Thus, to ensure the sustainable development of this country, only the exploitation of minerals (coltans, gold, cassiterites and gas) is not enough, if the agricultural sector does not play its role of providing food, to fight against poverty, create jobs and supply raw materials for other sectors and this should be included in the province's strategic plan for sustainable development (BWAMA, 2018).

Maize is one of the main foodstuffs, its cultivation is mainly carried out by very small peasant farms focused on family food security; its composition and nutritional value varies very significantly from one variety to another.

According to the US Department of Agriculture, the calorie content varies from 86 kilocalories per $100 \mathrm{~g}$ for wild yellow sweet corn ("corn, sweet, yellow, raw") to 386 kcal for yellow corn grain ("corn grain ") (https://en.wikipedia.org).

The data reported by FAO (2018) for maize for human consumption are carbohydrates: 72 to $73 \%$, slow sugar (starch) plus 1 to 3\% fast sugar (glucose, sucrose and fructose) or $18.8 \mathrm{~g}$ of carbohydrates per $100 \mathrm{~g}$ of corn; protein: 8 to $11 \%$; lipids: 3 to $18 \%$ (including $13 \%$ saturated fatty acids); dietary fiber ; minerals (concentration in $\mathrm{mg}$ per $100 \mathrm{~g}$ ) such as $\mathrm{P}, \mathrm{K}, \mathrm{Ca}, \mathrm{Mg}, \mathrm{Na}, \mathrm{Fe}, \mathrm{Cu}, \mathrm{Mn}, \mathrm{Zn}$; vitamins: A and $\mathrm{E}$; nutritional value: $99 \mathrm{kcal}$ (or $414 \mathrm{~kJ}$ ) per $100 \mathrm{~g}$; with the glycemic index: 65.

As for soya, which is a very important crop from a nutritional point of view and a good alternative to meat that is to say, it can compensate for animal proteins in household diets in Goma (North Kivu).

Soy is the only legume with a well-balanced protein composition (all essential amino acids are present). It provides useful energy through its complex carbohydrates. Free of lactose and cholesterol, it contains unsaturated fatty acids, while being low in saturated fatty acids (KAZUBA, 2014).

What to make of it a substitute of choice if you want to consume less meat or if you are vegetarian. Soy is also a source of vitamin B9, (cell renewal, very interesting for pregnant women for the development of the fetus, and in growing children, as well as for convalescent people), Source of vitamin B1 (heart function, energy, the nervous system); It contains vitamin C, iron, zinc, calcium, isoflavones, antioxidant compounds 
currently highly studied in the fight against cancer, cardiovascular diseases, osteoporosis and the symptoms of menopause (LABAT E., 2013).

Agronomically and technically, soy has the ability to fix atmospheric nitrogen via symbiosis with rhizobia and is also important for the sustainability of production systems where it enters into numerous combinations of crop rations (MAHAMAT, 2006).

Thus, the mixed cultivation of beans and corn on agricultural farms is one of the ways to overcome this challenge of the economic and social development of the Province.

The problem of this research is to determine the productivity of these two crops in association, namely corn and soybeans? How can these crops contribute to the fight against food insecurity, malnutrition and poverty in the region to ensure sustainable development?

Based on this interrogation, we believe that the productivity of the associated crops will depend on the genetic characteristics of each crop and the fertility gradient of the soil; in addition, low-cost consumption of these products can help households to fight food insecurity; And the presence of nutrients rich in protein, lipid, vitamins and different minerals would help improve health and fight against food insecurity, malnutrition and poverty in Sake (Goma).

\section{Environment and Methods}

The test was conducted at SAKE, a locality located west of the city of Goma in the KAMURONZA group in MASISI territory. This grouping is on horseback of the equator between $0^{\circ} 58 \mathrm{~min}$ of latitude North; $23 \mathrm{~min}$ south latitude; $29^{\circ} 58 \mathrm{~min}$ east longitude; $\quad 27 \quad 14 \mathrm{~min} \quad$ west longitude. Its soil is sand-clay of volcanic origin is cultivable, a second type of this soil comes from the wind deposits of volcanic ash, this soil is spread over the altitude of Lake Kivu (1460 to $2600 \mathrm{~m}$ above sea level). The area of extension of these wind farms is very large and includes part of the peninsula BOBANDANA, SAKE and KIROTSHE.

The climate is hot and humid with a temperature ranging between 20 and $25^{\circ}$ C, two rainy seasons and two dry seasons are noted, the rainy season (8 to 9 months), the big season starts in September and ends in December, the little one starts in February and finishes in April. For the dry season, the big begins in May and ends in August (3 to 4 months) while the small begins at the end of December and finished in February.

From a methodological point of view, we used an experimental device of randomized blocks comprising 5 treatments; T1: Pure Imperial soybean variety, T2: Pure Canada soybean variety, T3: Pure corn (Bamboo), T4: Imperial in association with corn, T5: Canada in association with corn; and 3 repetitions (blocks); with the use of the performance technique of crop associations by evaluating yield, biomass, quality (protein content), the LER = Land Equivalent Ratio.

Our field had a total of 15 plots and an area of $132 \mathrm{~m} 2$. 


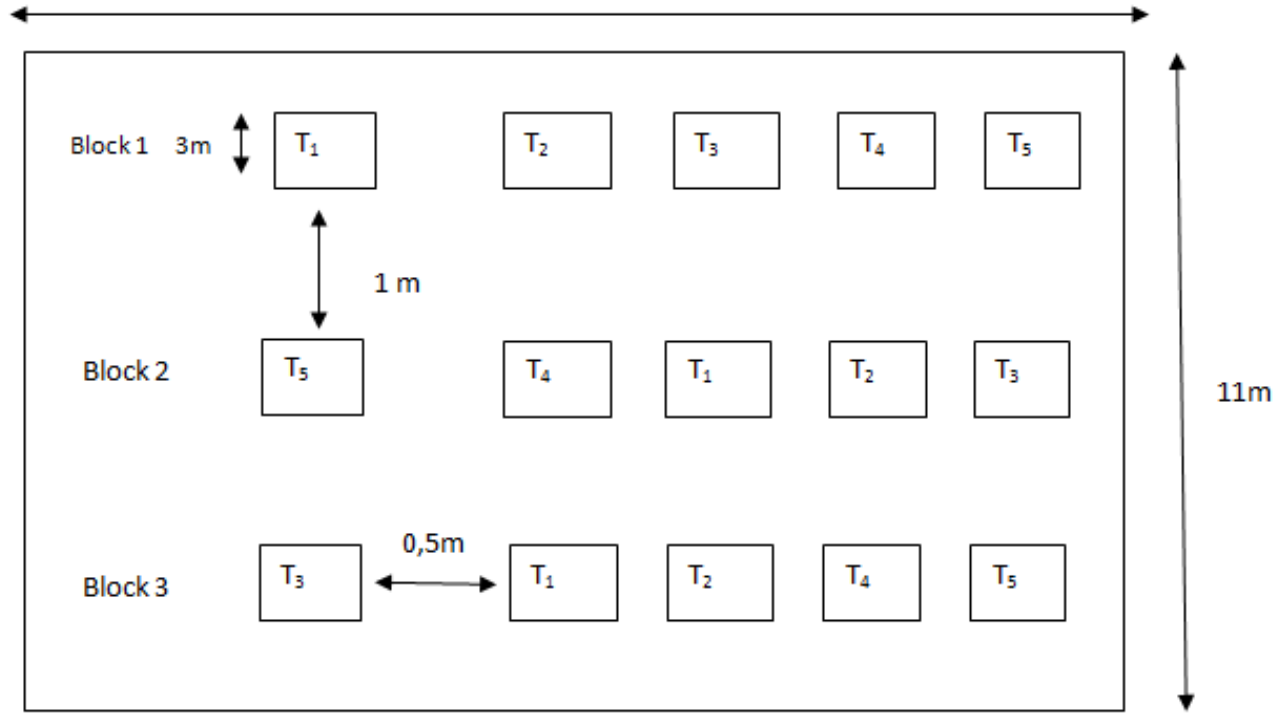

Legend: T1: Pure Imperial Soy Variety

T2: Pure Canada Variety of Soy

T3: Pure corn (Bamboo)

T4: Imperial in combination with corn

T5: Canada in association with corn.

The LER assesses the effectiveness of the association during its development cycle. It compares crop yields associated with crop yields alone. It corresponds to the area of specific mono crops required to obtain the same yield as in combination. It is calculated as follows:

$\mathrm{LER}=\frac{\text { Rendement céreale associ ée }}{\text { Rendement céréale seule }}+\frac{\text { Rendement céreale associ ée }}{\text { Rendement céréale seule }}$

If LER $=1$, there is no difference between the two culture modes; If LER $<1$, there is a loss of yield in association; If $L E R>1$, there is a productive advantage of associations

SYSTERRAperfcom(2012).

\section{Results}

Seeding of soybean and corn was done on the same day, March 25, 2018 in $3 \mathrm{~cm}$ deep pockets at 30x15cm spacing's for soybeans, with a density of 240 plants and 90x 25 $\mathrm{cm}$ for corn with a density of 63 plants and this because of 3 seeds per poquet.

The same spacings used in pure culture were also used in combination with a 2 : 1 arrangement (two lines for soybeans and one line for maize). The maintenance care performed was: hoeing, weeding, unmarking and ridging. The harvest of the Canada variety had taken place on the 15/07/2018 or 113 days after sowing, for the imperial variety and Bambou was the 22/07/2018 is 120 days after sowing. 


\subsection{Observation parameters}

The parameters observed are phrenological and productive as shown in Table 1, following.

Table 1: phrenological parameters of cultures

\begin{tabular}{|c|c|c|c|c|c|c|c|c|}
\hline \multirow[t]{3}{*}{ Prenological parameter of cultures } & \multirow[t]{3}{*}{ Blocks } & \multicolumn{7}{|c|}{ Jours écoulés } \\
\hline & & \multirow[t]{2}{*}{$\mathrm{T} 1$} & \multirow[t]{2}{*}{$\mathrm{T} 2$} & \multirow[t]{2}{*}{ T3 } & \multicolumn{2}{|l|}{ T4 } & \multicolumn{2}{|l|}{ T5 } \\
\hline & & & & & Imp & $\mathbf{B a}$ & $\mathrm{Ca}$ & $\mathbf{B a}$ \\
\hline \multirow[t]{4}{*}{ Du semis à la levée } & $\mathrm{I}$ & 8 & 9 & 7 & 8 & 7 & 9 & 7 \\
\hline & II & 8 & 9 & 7 & 8 & 7 & 9 & 7 \\
\hline & III & 8 & 9 & 7 & 8 & 7 & 9 & 7 \\
\hline & Moyenne & 8 & 9 & 7 & 8 & 7 & 9 & 7 \\
\hline \multirow[t]{4}{*}{ Du semis à la floraison } & $\mathrm{I}$ & 72 & 72 & 69 & 72 & 69 & 72 & 69 \\
\hline & II & 72 & 72 & 69 & 72 & 69 & 72 & 69 \\
\hline & III & 72 & 72 & 69 & 72 & 69 & 72 & 69 \\
\hline & Moyenne & 72 & 72 & 69 & 72 & 69 & 72 & 69 \\
\hline \multirow[t]{4}{*}{ Du semis à la récolte } & $\mathrm{I}$ & 120 & 113 & 120 & 120 & 120 & 113 & 120 \\
\hline & II & 120 & 113 & 120 & 120 & 120 & 113 & 120 \\
\hline & III & 120 & 113 & 120 & 120 & 120 & 113 & 120 \\
\hline & Moyenne & 120 & 113 & 120 & 120 & 120 & 113 & 120 \\
\hline
\end{tabular}

Source: Expermentation, juillet 2018

\subsection{Production}

The results obtained take into account two crops in association, namely soybeans and maize in the agro-ecological conditions of Sake / Masisi (North Kivu).

\subsubsection{Soy}

Table 2: Parcel Production of Soybeans

\begin{tabular}{lcc}
\hline Traitment & Mean & Ecart type \\
\hline T1 & 123,33 & $\pm 30,55$ \\
T2 & 141,66 & $\pm 16,07$ \\
T4 & 64,33 & $\pm 13,65$ \\
T5 & 48,33 & $\pm 7,63$ \\
CV & & 20,9 \\
Décision & & $\mathrm{S}$ \\
PPDS & & 34,18
\end{tabular}

\section{Source: Genstat Analysis, May 2019}

From this table $\mathrm{n}^{\circ} 3$, it is announced a heterogeneity of soy production in the blocks and plots for T4, T1, T2 and T5; their CV (\%) is greater than 15\%, ie the production 
data is scattered around the mean, which proves that soybean production differs from one block to another and one treatment to another.

The analysis of variance by the DUNNET test at the $5 \%$ probability threshold shows that there is a significant difference between the treatments implemented in our experimental setup, that is to say, we accept the alternative hypothesis ( H1) and reject the null hypothesis (Ho).

This result encourages the mixed cropping system at SAKE / GOMA and positively impacts organic and sustainable agriculture, which contributes to the economic development of the region, which at times constitutes a focus of the various tensions related to the management of land capital between ethnic groups. (PNSD, 2016).

We can illustrate the means of production, in Figure 1, as follows:

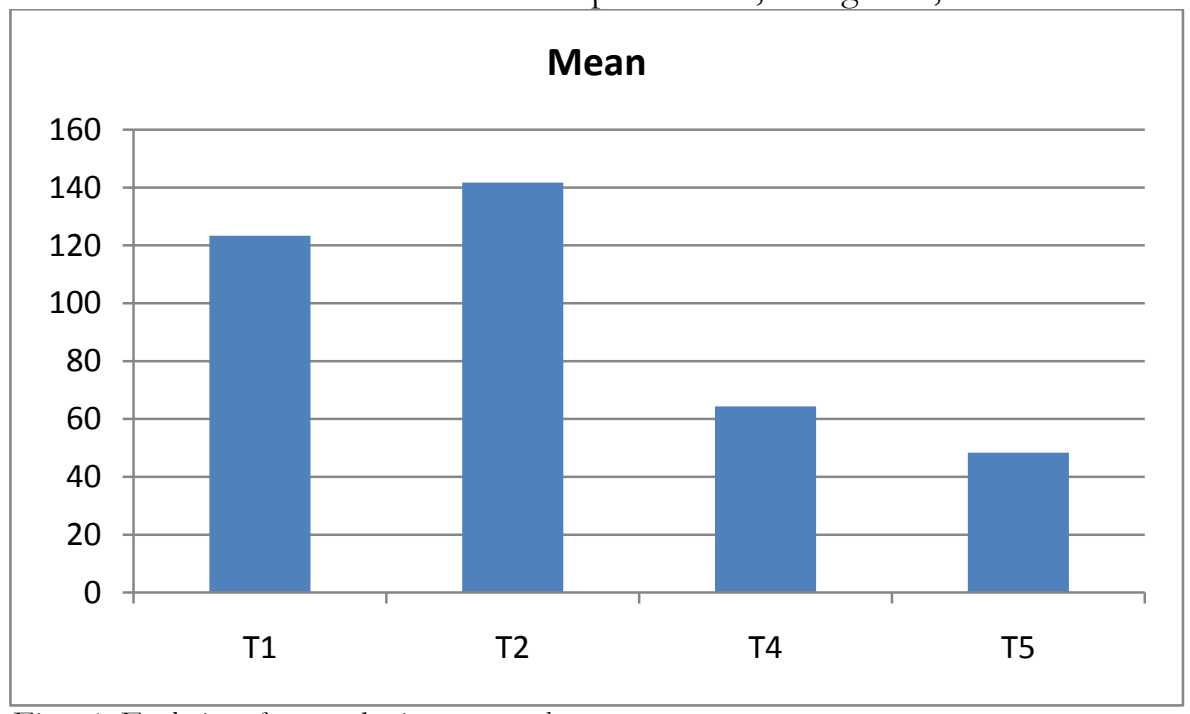

Figure1: Evolution of soy production averages by treatment.

We find that among all the soybean production averages, the $\mathrm{T} 2$, occupies the first position is $140 \mathrm{~kg} /$ plot, followed by T1 with at least $120 \mathrm{~kg} /$ plot and the last position is reserved for T5 with at least $40 \mathrm{~kg} /$ plot. This demonstrates a high productivity of culture in this Sake space.

This graph1 confirms the significant difference between T2 and T1 averages compared to T4, T5.

\subsubsection{Corn}

This crop has become one of the most consumed cereals in Sub-Saharan Africa and in the world with various uses in communities and in the world (ROUANET G., 1990). 
Table 3: Parcel production of maize

\begin{tabular}{lcc}
\hline Traitement & Mean & Ecartype \\
\hline T3 & 303,33 & $\pm 35,11$ \\
T4 & 350 & \pm 60 \\
T5 & 43,33 & $\pm 40,41$ \\
CV & 13,6 & \\
Décision & & NS \\
PPDS & - &
\end{tabular}

\section{Source: analysis genstat}

At the end of this table $\mathrm{n}^{\circ} 3$, it is announced a homogeneity of the data for the treatment T3, T4 because their CV is lower than $15 \%$, that is to say the data of parcel production of maize are regrouped around the average.

The comparison of variance means by the DUNNET test at the $5 \%$ threshold shows that there is no significant difference between the treatments. What we observe may be due to climatic hazards, edge effects ...

However, thanks to the illustration in Figure 2, we find the following:

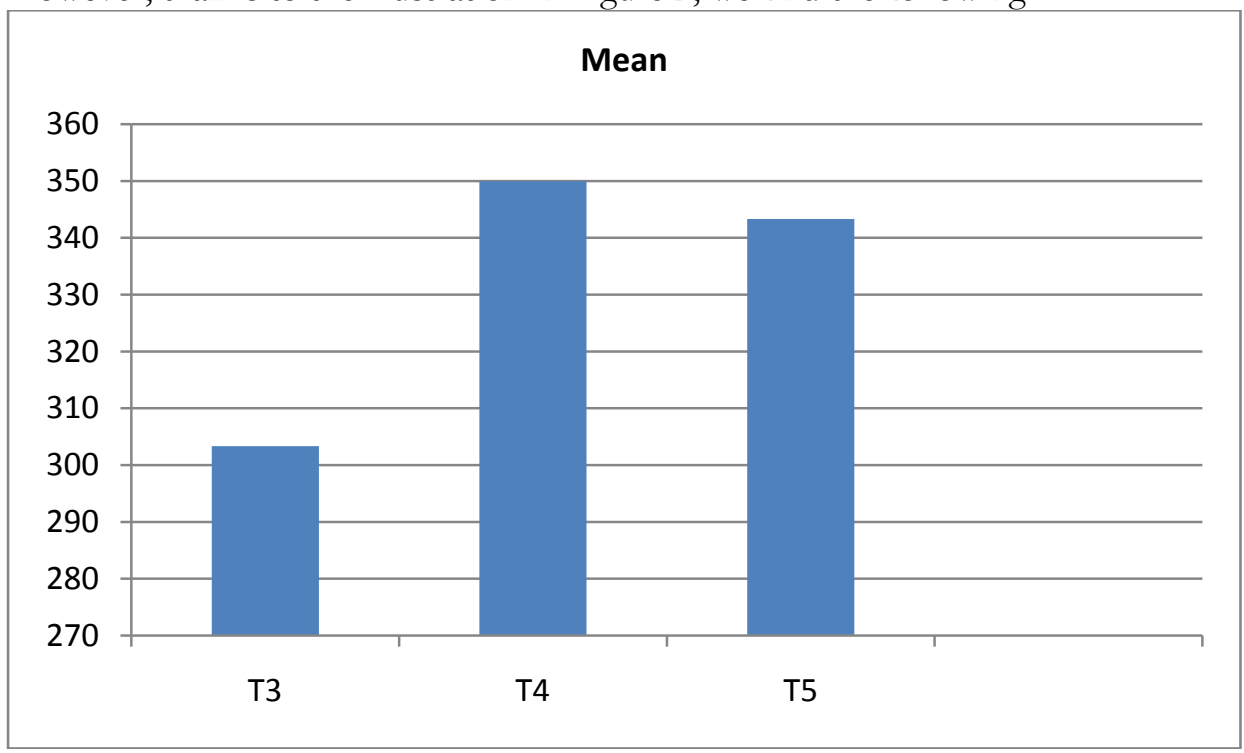

Figure2: Evolution of corn production averages by treatment.

Between T3 and T4, T5, there is a significant difference in maize production averages per plot, during our field trial.

\subsubsection{Crop yield}

After field experimentation, yield-related results are expressed in tonnes per hectare ( $\mathrm{t} / \mathrm{ha}$ ). This is a requirement in agronomic techniques to measure production in this area. However, from an economic point of view, it is a question of an average 
productivity of labor and capital invested as factors of production (CIRAD and GRET, 2009).

For this research, we will go from one crop to another to measure the yields of the associated crops (soy and corn).

\subsubsection{Soy}

As stated above, here are the soy yields in Table 4, below:

Table n.4: yield in tons / ha

\begin{tabular}{llc}
\hline Traitement & Mean & Ecart type \\
\hline T1 & 0,205 & $\pm 0,05$ \\
T2 & 0,233 & $\pm 0,023$ \\
T4 & 0,104 & $\pm 0,022$ \\
T5 & 0,278 & $\pm 0,33$ \\
CV & 20,5 & \\
Décision & $\mathrm{S}$ & \\
PPDS & 0,29 &
\end{tabular}

Source : Analyse Genstat

From this table 4, we see that the treatments are heterogeneous because their CVs are higher than 15\%. Analysis of variance (ANOVA) shows a non-significant difference between treatments.

The yield per ton per hectare was estimated by extrapolating the average plot production of 4 treatments at one hectare scale. In an agricultural process, the yield of soy varies according to the genotype, the cropping system, the level of development of agriculture, ecology and the environment of the environment (NIEUWEHUIS R, 2005).

In the world, the average yield of seeds varies between 550 and $2200 \mathrm{~kg} / \mathrm{ha}$. Suitable cultivars, subject to good management can produce 3500 to $5000 \mathrm{~kg} / \mathrm{ha}$ (for this research, A Goma (SAKE), we managed to obtain a yield by extrapolation $2780 \mathrm{~kg} / \mathrm{ha}$, with $\quad$ T5 and $1040 \quad \mathrm{Kg} / \mathrm{ha}$ for This confirms the fertility of the Goma (Sake) soil, which is a volcanic and nutrient-rich soil for this crop (ECOCONSO, 2013). These results do not differ from those mentioned by (RAEMAEKERS, 2001).

In the small-scale agriculture sectors, as in Africa, the yields are generally lower and range from 480 to $660 \mathrm{~kg} / \mathrm{ha}$, these poor results can be explained by various factors such as poor soil management, poor farming technique varieties of lower productivity, loss of germinative power, etc.

\subsubsection{Corn}

This cereal is at the top of the list in terms of demand for staples in the DRC and Africa compared to rice, sorghum and wheat. Table 5 gives the maize yield per hectare. 
Table 5: Yield of maize / ha

\begin{tabular}{lcc}
\hline Traitement & Moyenne & Ecart type \\
\hline T3 & 0,50 & $\pm 0,06$ \\
T4 & 0,58 & $\pm 0,1$ \\
T5 & 0,57 & $\pm 0,06$ \\
CV & 13,7 & \\
Décision & $\mathrm{S}$ & \\
PPDS & - &
\end{tabular}

Source: Genstat Analysis

In view of this table 5 , we see that the treatments presented a homogeneity of the data and results that it is heterogeneous for (T2); because their CV is less than $15 \%$. This shows that there is aggregation of data around the average through the different treatments and in each block.

The variance analysis at the 5\% probability level shows a no significant difference between treatments, that is, we accept the null hypothesis (Ho) and reject the alternative

hypothesis

We can confirm that the nutrient homogeneity of the soil also influences the different yields obtained during this experiment. If it prefers rich soils, maize can still grow in sandy soil if irrigated and fertilized (PODA E, 1979).

It is a crop that prefers deep, rich soils but can cope with more difficult conditions, such as sandy soils or more clayey or even limestone, provided it provides the necessary water and nutrients (RAEMAEKERS, R, 2011).

It is an improving crop thanks to its deep rooting and its important contributions of organic matter ensured by crop residues. Unlike other cereals, the mechanized maize crop is a root crop, which is useful for controlling weeds and especially limiting water losses. From this perspective in Africa, maize contributes to sustainable land use (SYSTERRA Perf com, 2012).

According to the FAO (2018), for corn intended for human consumption we have the following elements: carbohydrates: 72 to $73 \%$ of slow sugar (starch) plus 1 to $3 \%$ of fast sugar (glucose, sucrose and fructose); protein: 8 to 11\%; lipids: 3 to 18\% (including 13\% saturated fatty acids); dietary fiber ; minerals (P, K, Ca, $\mathrm{Mg}, \mathrm{Na}, \mathrm{Fe}, \mathrm{Cu}$, Mn, Zn); vitamins: A and E; with a nutritional value of $99 \mathrm{kcal}$ (or $414 \mathrm{~kJ}$ ) per $100 \mathrm{~g}$ ).

Performance calculation by extrapolation.

The yield in tonnes per hectare of maize was estimated by extrapolating the average of the plot production of 4 treatments at the scale of one hectare. The performance of the associations was as follows:

Imperial: L.E.R $=\frac{0,58}{0,50}+\frac{0,104}{0,205}=1,6$, L.E.R $>1$ (there is a productive advantage in this association with bamboo maize); 
Canada: L.E.R $=\frac{0,57}{0,50}+\frac{0,278}{0,233}=2,33$, L.E.R $>1$ (there is a productive advantage in this association with bamboo maize).

In partial conclusion, the two cultures in association offer a good possibility of land management and guarantee food security by increasing the productivity, accessibility, price and the consumption of the population of each of them in this vital space of the DRC.

\section{Discussions}

As we have seen from the results obtained, the analysis of the vegetative cycles of our soybean varieties, shows us that there were no significant differences between our varieties tested, with a vegetative cycle ranging from 113 days for the variety canada and 123 days for the imperial variety from sowing to harvest.

These results do not differ from those of STANTON (1970), who tells us that the vegetative cycle of soybeans is 110 to 130 days for late types. The seeds rose almost homogeneously in the different soybean treatments and in the blocks.

We find that the treatments presented a homogeneity of the data and results that it is heterogeneous for (T2); because their CV is less than $15 \%$, for corn, on the other hand, for soy, we see that the treatments are heterogeneous because their CVs are higher than $15 \%$. Analysis of variance (ANOVA) shows a non-significant difference between treatments. This result reveals the independence of each culture in terms of production despite the association between the two (MATUSSO, 2014).

In treatments where both varieties are associated with maize, maize is more competitive than soybean, this was also mentioned by MVONDO (1984).

According to the performances of the association, the two varieties gave in L.E.R > 1, this corresponds with the study of YILMAZ (2009) which shows that L.E.R. the soybean maize association is often greater than 1 , which is explained by a better valorization of the radiation at the beginning of the cycle and the increase of the productivity of its two cultures.

Based on the results in Tables 4 and 5; and in terms of nutrition and health, we see that these two sister crops (soya and maize) are better placed to fight against malnutrition in this environment because of the different nutrients they contain for human consumption, especially children of 0 to 5 years old (UNCTAD, 2016).

In addition, in breeding, they are important nutritional supports for animals (AHMADI $\mathrm{N}$, et al, 2002).

Finally, in final conclusion, From a sustainable development point of view, these crops contribute by their biomasses, the maintenance of soil fertility and the storage of carbon. In terms of land use in the region, the combination of soybean and maize limits the extensive exploitation of arable land and agricultural land conflicts in the region, as it promotes intensive farming and sedentary long-term farmers.

Finally, there is a need to encourage such an association of culture for sustainable development, of which the agricultural sector is one of the pillars. 


\section{References}

Ahmadi N., Chantereau J. Hekimian letheve c. Et Ouendeba B., 2002 ; les céréales, In memento de l'agronome, Paris

Baku,F, 2009, Ecocongo

Bwama, M, 2018 : Exploitation des Minerais et relance de l'agriculture à Nord Kivu, CRIDUPN, 2018, Kinshasa, RDC

Canada et IMPERIALE) dans les conditions écologiques de MUNIGI.(mémoire)

Cirad et GRET, 2009, Mémento de l'agronome, ministère de coopération française, Paris

Cnuced, 2016, Soja, New-York et Genève

ECOCONSO du conseil à l'action, 2013, association de cultures, Fiche-conseil no 77

FAO, 2009, Rapport national sur l'Etat des ressources phylogénétique pour l'alimentation et l'agriculture, R.D.C FAO, 2018 : Rapport sur les céréales, Rome, Italie

Kazuba S., 2014, Le potentiel de production de quelques variétés du soja (SB24,

Krooll, 1994, les cultures maraichères, maison neuve

Labat E., 2013, le soja : Influence de sa consommation sur la santé bumaine et conséquences de l'expansion de sa culture au niveau mondial

Mahamat, 2006, Etude de l'association des graminées pérennes Andropogon gayanus var. bisquamulatus et panicum maximum var. C1 avec les légumineuses Arachis Hypogea var Fleur 11 et Vigna unguiculata var 58.74 (Ouvrage)

Matusso, 2014, effect of maize - Soybean intercropping fratterns on yield and soil propecties in too contrasting sites, Kenya.

Mvondo Nkodo, 1984, Etude des principales caractéristiques de l'association culturale maïs (ZeaMays L.) Soja (Glycine max. L Menill L) dans les conditions écologiques de Dschang

Nieuwehuis R., 2005, La culture du soja et d'autres légumineuses. Fondation agronomica

Poda E., 1979, L'amélioration du maïs pour la productivité et la valeur nutritionnelle. Etude de la prolificité en épis et des facteurs de richesse en Lycine du grain, INR A Montpellier, France

PNSD, 2016 : Programme National Stratégique de Développement, Kinshasa, RDC, Primature

Raemaekers R, 2001, l'agriculture en Afrique tropicale, Bruxelles

Rouanet G., 1984, le maïs, maison neuve et Larose.142 p (Ouvrage)

Rouanet G., 1990, le maïs, maison Rewvel, Paris, 67 p (Ouvrage)

Ruremesha K, 2018 : Gouvernance du capital foncier et agricole, Masisi, Nord Kivu, RDC

Stanton, 1970, les légumineuses à graines en Afrique, Rome,199p (Ouvrage)

SYSTERRA Perf com, 2012, les Cultures Associés, INERA, (Ouvrages)

Yilmaz ,2009, An investigation on quality parameters at the silages made by corn and soybean grocum in different seeding rates, animal and veterinary Advances,pp 1856-1859 (Ouvrage).

https:// fr.wikipedia.org, Consulté le 15 mai 2019 